\title{
Natalia Kalinowska
}

Uniwersytet Kardynała Stefana Wyszyńskiego

\section{ELEKTRONICZNE DOWODY OSOBISTE}

\section{WSTĘP}

Elektroniczne dowody osobiste jeszcze do niedawna stanowiły odległą przyszłość. Dopiero w latach 90. ubiegłego wieku zdecydowano się na zmianę dowodów w postaci książeczki na nowoczesną kartą z tworzywa sztucznego ${ }^{1}$, co nastąpiło dopiero w 2007 r. Pierwsze poważne zmiany w zakresie elektronicznych dowodów tożsamości miała przynieść ustawa z 6 sierpnia 2010 r. o dowodach osobistych². Przepisy ustawy miały zacząć obowiązywać od 1 lipca 2011 r., ostatecznie jednak usunięto z niej przepis o warstwie elektronicznej dowodu osobistego ${ }^{3}$. Polska jest jednym z niewielu krajów europejskich, w których nie wprowadzono jeszcze elektronicznych dowodów osobistych. Nowe dowody mają przede wszystkim upowszechnić dostęp do e-administracji, oprzeć procesy w administracji publicznej wymagające interakcji z obywatelem

1 K. Czaplicki, Dokumenty tożsamości. Jawność i bezpieczeństwo, Warszawa 2016, s. 97.

2 Tekst jedn.: Dz. U. z 2016 r. poz. 391.

$3 \quad$ K. Czaplicki, op. cit., s. 123. 
na kontakcie elektronicznym (zdalnie przez Internet), a także usprawnić procesy wymagające identyfikacji w świecie fizycznym ${ }^{4}$.

Artykuł wyjaśnia podstawowe pojęcia, takie jak „dokument”, „tożsamość”, objaśnia genezę dokumentów tożsamości, w tym dowodów osobistych. Wyjaśnia znaczenie ustawy o usługach zaufania publicznego i identyfikacji elektronicznej, a także rozporządzenia Parlamentu Europejskiego i Rady (UE) nr 910/2014 w sprawie identyfikacji elektronicznej i usług zaufania publicznego w odniesieniu do transakcji elektronicznych na rynku wewnętrznym oraz uchylającego dyrektywę 1999/93/WE. Opisane zostały dotychczasowe działania podejmowane w celu wprowadzenia w Polsce elektronicznych dowodów tożsamości oraz działania podejmowane obecnie. W podsumowaniu zawarto korzyści wynikające wprowadzenia dowodów osobistych z warstwą elektroniczną, jak również obawy związane z funkcjonalnością i bezpieczeństwem systemu.

\section{PojęCie dokumentu i pojęCIE tożsamości}

\subsection{Pojęcie dokumentu}

Słowo „dokument” pochodzi od łacińskiego słowa documentum. Pojęcie to co do zasady kojarzy się z czymś istotnym, ważnym, mogącym mieć wpływ na czyjeś prawa, stanowiącym potwierdzenie określonych okoliczności. Świadczą o tym definicje słownikowe dokumentu, stanowiące odbicie powszechnego znaczenia i rozumienia wyrazów ${ }^{5}$. Zgodnie z Uniwersalnym słownikiem języka polskiego PWN za dokument uznaje się między innymi dowód stwierdzający czyjąś tożsamość, na przykład dowód osobisty, legitymacja, paszport ${ }^{6}$. Popularny słownik języka polskiego wskazuje natomiast, że jest to druk urzędowy wystawiony na

4 Por. Koncepcja e-Dowód - kontynuacja projektu pl.ID i realizacja powiązanych projektów, s. 3.

5 J. B£ACHut, Dokument jako przedmiot ochrony prawnokarnej, Warszawa 2011, s. 15.

6 S. Dubisz, Uniwersalny słownik języka polskiego PWN, t. A-J, Warszawa 2006, s. 647. 
określone nazwisko, opatrzony zdjęciem posiadacza i zawierający dane pozwalające stwierdzić jego tożsamość ${ }^{7}$. W literaturze podkreśla się, że współcześnie pojęcie dokumentu ewoluuje w kierunku określonej treści utrwalonej na piśmie, co jest jego cechą charakterystyczną, coraz rzadziej zaś wykorzystuje się je w odniesieniu do innych przedmiotów, na przykład „budowla ta jest dokumentem epoki”8. Jak wskazuje Kajetan Wojsyk, istotną cechą dokumentu jest bowiem jego utrwalenie, na przykład przez utrwalenie treści, która jest sama w sobie niematerialna, ulotna jak - mówiąc potocznie - słowo rzucone na wiatr. Dopiero utrwalenie tej treści, czyli związanie jej z jakimś materialnym nośnikiem (kartką papieru, taśmą magnetyczną, dyskiem magnetycznym lub optycznym itp.), powoduje, że może stać się ona dokumentem9.

$\mathrm{W}$ polskich przepisach pojęcie dokumentu jest wielokrotnie używane. W ustawie z 23 kwietnia 1964 r. - Kodeks cywilny ${ }^{10}$ w art. $77^{3}$ za dokument uznaje się nośnik informacji umożliwiający zapoznanie się z jej treścią. Mając na uwadze funkcje, jakie pojęcie dokumentu ma spełniać w poszczególnych gałęziach prawa, wydaje się, że brak jest możliwości pełnego ujednolicenia terminologii w tym zakresie.

W art. $115 \$ 14$ ustawy z 6 czerwca 1997 r. - Kodeks karny ${ }^{11}$ dokument został zdefiniowany jako każdy przedmiot lub inny zapisany nośnik informacji, z którym jest związane określone prawo, albo który ze względu na zawartą w nim treść stanowi dowód prawa, stosunku prawnego lub okoliczności mającej znaczenie prawne. Definicja przyjęta w kodeksie karnym obowiązuje również w ustawie z 20 maja 1971 r. - Kodeks wykroczeń ${ }^{12}$ oraz w ustawie z 10 września 1999 r. - Kodeks karny skarbowy ${ }^{13}$.

\footnotetext{
7 B. Dunaj, Popularny słownik języka polskiego, Warszawa 2001, s. 98.

8 K. Knoppex, Dokument w procesie cywilnym, Poznań 1993, s. 12.

9 K. Woנsyк, Dokument jaki jest każdy widzi... a jaki będzie?, «Człowiek i Dokumenty»15/2009, s. 9.

10 Tekst jedn.: Dz. U. z 2018 r. poz. 1025.

11 Tekst jedn.: Dz. U. z 2017 r. poz. 2204.

12 Tekst jedn.: Dz. U. z 2018 r. poz. 618.

13 Tekst jedn.: Dz. U. z 2017 r. poz. 2226.
} 
W ustawie z 14 czerwca 1960 r. - Kodeks postępowania administracyjnego $^{14}$ brak definicji legalnej tego pojęcia, jednakże w doktrynie wielokrotnie podejmowano próby zdefiniowania, czym jest dokument ${ }^{15}$.

\subsubsection{Dokument urzędowy}

Zgodnie z art. 244 ustawy z 17 listopada 1964 r. - Kodeks postępowania cywilnego ${ }^{16}$ i art. 76 k.p.a. dokumentem urzędowym jest dokument sporządzony w przepisanej formie przez powołane do tego organy władzy publicznej i inne organy państwowe w zakresie ich działania. Dokument urzędowy stanowi dowód tego, co zostało w nim urzędowo zaświadczone. Dokument urzędowy korzysta więc z domniemania zgodności z prawdą tego, co zostało w nim urzędowo zaświadczone, oraz z domniemania prawdziwości (autentyczności pochodzenia takiego dokumentu od jego wystawcy) ${ }^{17}$. Artykuł $76 \$ 3$ k.p.a. dopuszcza obalenie domniemania zgodności z prawdą dokumentu urzędowego w drodze przeprowadzenia dowodu przeciwko treści (osnowie) takiego dokumentu. Za słuszny należy uznać pogląd, zgodnie z którym nie wyklucza to przeprowadzenia dowodu zaprzeczającego samej autentyczności dokumentu ${ }^{18}$.

Od 2015 r. nie ma już w polskich przepisach listy podmiotów uprawnionych do sporządzania dokumentów urzędowych ${ }^{19}$. Należy podzielić pogląd Tomasza Demendeckiego, zgodnie z którym termin „organy

14 Tekst jedn.: Dz. U. z 2017 r. poz. 1257.

15 M.in. M. JAśKowsKa (M. JAśKowsKA, A. WróBel, Komentarz aktualizowany do ustawy z dnia 14 czerwca 1960 r. - Kodeks postępowania administracyjnego, Warszawa 2016, s. 522) i E. Ochendowski (E. Ochendowski, Postępowanie administracyjne ogólne, egzekucyjne i sądowoadministracyjne. Wybór orzecznictwa, Toruń 2010, s.126).

16 Tekst jedn.: Dz. U. z 2018 r. poz. 1360.

17 T. Demendecki, Komentarz aktualizowany do art. 244 kodeksu postępowania cywilnego, [w:] Kodeks postępowania cywilnego. Komentarz aktualizowany, I, Art. 1-729, red. A. JAKUBECKI, Warszawa 2018, s. 441.

18 M. JAśKowska, A. WróBel, Komentarz aktualizowany do ustawy z dnia 14 czerwca 1960 r. - Kodeks postępowania administracyjnego, Warszawa 2016, s. 524.

19 Zmiana ta wynikała $\mathrm{z}$ uchwalenia ustawy z 10 lipca 2015 r. o zmianie ustawy Kodeks cywilny, ustawy - Kodeks postępowania cywilnego oraz niektórych innych ustaw (Dz. U. poz. 1311). 
władzy publicznej” obejmuje zarówno organy administracji państwowej, jak i organy samorządu terytorialnego ${ }^{20}$. Taki organ, mimo że nie sporządza dokumentu w sensie technicznym i materialnym, uznaje się za wystawcę dokumentu.

W polskim prawie pojęcie dokumentu urzędowego zostało wprowadzone także w ustawie z 6 września 2001 r. o dostępie do informacji publicznej ${ }^{21}$. Zgodnie z art. 6 ust. 2 tej ustawy dokumentem urzędowym jest treść oświadczenia woli lub wiedzy, utrwalona i podpisana w dowolnej formie przez funkcjonariusza publicznego (w rozumieniu przepisów kodeksu karnego), w ramach jego kompetencji, skierowana do innego podmiotu lub złożona do akt sprawy. Zgodnie z art. 115 pkt 4 k.k. w zw. $\mathrm{z}$ art. 4 ust. 1 pkt 1 lit. c ustawy z 21 listopada 2008 r. o pracownikach samorządowych ${ }^{22}$, funkcjonariuszem publicznym jest osoba będąca pracownikiem samorządu terytorialnego, którym w urzędzie gminy jest wójt (burmistrz, prezydent miasta).

Definicja z ustawy o dostępie do informacji publicznej nie wprowadza szczegółowych wymogów co do formy dokumentu, wprost wskazując, że może on zostać utrwalony i podpisany w dowolnej formie. Wydaje się przy tym, że dowolność formy dotyczy zarówno utrwalenia, jak i podpisania dokumentu. W rozumieniu ustawy o dostępie do informacji publicznej konieczne jest, aby dokument urzędowy spełnił oba te warunki. Skutkiem tego dokument, który nie został podpisany (w jakiejkolwiek formie), nie będzie mógł być uznany za dokument urzędowy.

\subsection{Pojęcie tożsamości}

Pojęcia tożsamości (łac. identitas, ang. identity, fr. identité, niem. Identität) używa się w języku potocznym, literackim, opracowaniach naukowych czy języku prawniczym²3. W literaturze wskazuje się, że termin „tożsamość” wywodzi się z łacińskiego idem, oznaczającego identyczność i ciągłość, jednak dopiero w XX w. pojawił się on w potocznym

20 T. DEMENDECKI, op. cit., s. 441.

21 Tekst jedn.: Dz. U. z 2018 r. poz. 1330.

22 Tekst jedn.: Dz. U. z 2018 r. poz. 1260.

23 A. LACH, Karnoprawna reakcja na zjawisko kradzieży tożsamości, Warszawa 2015, s. 15. 
użyciü2 . Popularny słownik języka polskiego słowo „tożsamość” wręcz zrównuje ze słowem „identyczność”. Witold Doroszewski wskazuje, że tożsamość to bycie tym samym, identyczność oraz tożsamość kogo (czyjej osoby). Tożsamość w tym drugim znaczeniu to fakt, że ktoś jest tą osobą, za którą się podaje lub uważa; fakt, że ktoś nosi takie, a nie inne nazwisko ${ }^{25}$. Pojęciem tożsamości wielokrotnie operują kodeks karny oraz ustawa z 6 czerwca 1997 r. - Kodeks postępowania karnego ${ }^{26}$. Z kolei kodeks cywilny używa słowa „tożsamość” sześciokrotnie ${ }^{27}$ w kontekście rzeczy oznaczonej co do tożsamości. W kodeksie postępowania cywilnego słowo „tożsamość” poza kontekstem wskazanym w kodeksie cywilnym występuje w art. $307 \$ 2$ : „Sprawozdanie z grupowego badania krwi powinno zawierać stwierdzenie, czy sprawdzono należycie tożsamość osób, których krew pobrano”, oraz w art. 543: „Jeżeli osoba, którą uznano za zmarłą lub której zgon stwierdzono, zjawi się osobiście w sądzie i wykaże swoją tożsamość”. Trudno z kolei doszukiwać się pojęcia „tożsamość” w kodeksie postępowania administracyjnego czy w ustawie z 30 sierpnia 2002 r. - Prawo o postępowaniu przed sądami administracyjnymi ${ }^{28}$. Mimo to WSA w Warszawie podjął się jego wykładni, stwierdzając, że w języku polskim pojęcie „tożsamość” oznacza cechy, które stanowią o tym, kim dana osoba jest, czym różni się od innych. Na tak rozumianą tożsamość składa się nie tylko to, kim się jest obecnie, ale także to, kim się było, a nawet zamierzenia na przyszłość; wszystko to powoduje, że dana osoba różni się od innej.

Można przyjąć, że każda osoba ma inną tożsamość, tzn. nie ma dwóch osób, które posiadałyby identyczne wszystkie dane osobowe. Może się oczywiście zdarzyć, że dwie osoby mają to samo imię i nazwisko, datę lub miejsce urodzenia, a nawet zbliżony wygląd fizyczny. Jednak takie dane identyfikujące jak PESEL, numer dowodu osobistego będą zawsze inne,

24 G. MarshalL, Słownik socjologii i nauk społecznych, Warszawa 2004, s. 402.

25 W. Doroszewski, Słownik języka polskiego, IX, Warszawa 1967, s. 206.

26 Np. art. 12 k.k. (tożsamość pokrzywdzonego), art. 274 k.k. (dokument stwierdzający tożsamość), art. $184 \$ 1$ k.p.k. (tożsamość świadka), art. $213 \$ 1$ k.p.k. (tożsamość oskarżonego).

${ }_{27}$ Art. $155 \$ 1$, art. 478, 976, 977, 978, $981^{1} \$ 1$ k.c.

28 Tekst jedn.: Dz. U. z 2018 r. poz. 1302. 
a prawdopodobieństwo identyczności takich danych jak kod DNA czy linie papilarne jest bardzo niskie ${ }^{29}$. Z drugiej strony jednak posiadanie określonej tożsamości nie wyklucza jej zmiany na przykład w wyniku zmiany nazwiska lub zmiany płci. Tożsamość jest bez wątpienia czymś, czego jednostka potrzebuje, aby właściwie funkcjonować w społeczeństwie, wchodzić w interakcje z innymi ludźmi, dokonywać czynności prawnych. Weryfikacja tej tożsamości ma miejsce w różnych sytuacjach, przy czym stopień weryfikacji może być różny: od odebrania oświadczenia od danej osoby, przez przedstawienie dokumentów tożsamości do kontroli biometrycznej ${ }^{30}$.

\section{Dowód osobisty}

Dowód osobisty jest pojęciem węższym od pojęcia dokumentu tożsamości. Dokumentem tożsamości może być paszport, prawo jazdy, legitymacja studencka czy wreszcie dowód osobisty. Pierwsze dokumenty tożsamości na kontynencie europejskim pojawiły się na przełomie XVI i XVII w. Były to głównie paszporty i różnego rodzaju legitymacje służące identyfikacji posłańców przekazujących międzynarodową pocztę ${ }^{31}$. Potrzeba wprowadzenia systemu dokumentów potwierdzających tożsamość jednostek pojawiła się w okresie siedemnastowiecznych wojen religijnych, w związku z przemarszami wojsk, i będącymi ich konsekwencją przemieszczeniami ludności cywilnej, czy wreszcie w związku z tworzeniem się państw narodowych zajmujących ściśle określone terytoria $^{32}$. W Polsce dowody osobiste wprowadzono w latach 20. Było to koniecznym elementem unifikacji państwa odrodzonego po I wojnie światowej, w którym były miliony ludności z Austrii, Niemiec i Rosji. Wielu nie miało kompletnie żadnych dokumentów ${ }^{33}$.

\footnotetext{
29 A. LACH, op. cit., s. 19.

30 Ibidem, s. 20.

31 K. Czaplicki, op. cit., s. 83.

32 E. Mordini, Biometria i biopolityka, «Człowiek i Dokumenty» 8/2008, s. 19-20, http://www.cssc.eu/public/STYCZEN.pdf ( dostęp 4 października 2016 r.).

33 A. Dryszel, Historia dowodów osobistych, «Przegląd» nr 50 z 12 grudnia 2004 r.
} 
W Polsce dowody tożsamości pojawiły się w 1918 r., zaraz po odzyskaniu niepodległości. Zgodnie z art. 2 rozporządzenia MSW z 30 listopada 1918 r. ${ }^{34}$ każdy obywatel od lat 15 przebywający w granicach RP powinien posiadać dowód osobisty ${ }^{35}$. Jak zauważa Andrzej Dryszel, podczas wyrabiania dowodów osobistych po I wojnie światowej nie stosowano przesadnego rygoryzmu. Wprawdzie teoretycznie należało mieć metrykę urodzenia, ale bardzo wielu ludzi stwierdzało, że dokumenty zaginęły w pożodze wojennej, i przedstawiało tylko oświadczenia świadków, że są przez nich znani, podają prawdziwą datę oraz miejsce urodzenia. Przy tej okazji panie, jak głoszą liczne podania rodzinne, nader często podawały znacznie późniejszą datę urodzenia, by mieć mniej lat w dowodzie, a tym samym więcej szans na korzystne zamążpójście. To samo czynili panowie pragnący odwlec przykry moment rozpoczęcia służby wojskowej ${ }^{36}$.

Na mocy rozporządzenia Prezydenta RP z 1928 r. organy uzyskały prawo do wydawania krajowych dokumentów tożsamości, które ułatwić miały proces legitymowania się przed organem administracji publicznej kontrolującym ruch ludności ${ }^{37}$. Organem, który na mocy wspomnianego rozporządzenia został zobligowany do wystawiania dowodów osobistych, była gmina. Pierwsze dowody osobiste nie były obowiązkowe. Rozporządzenie formułowało tylko prawo do posiadania dowodu osobistego, nie wprowadzając w tym zakresie obowiązku ${ }^{38}$. Instytucja dowodu osobistego, mimo istotnej rekonstrukcji przepisów ewidencyjnych w 1932 r., nie zmieniła się do roku 1951, kiedy to - w nowych uwarunkowaniach polityczno-społecznych - 22 października $1951 \mathrm{r}$. został wydany przez Radę Ministrów dekret o dowodach osobistych ${ }^{39}$.

34 Rozporządzenie Ministra Spraw Wewnętrznych z 30 listopada 1918 r. (M.P. Nr 223), dotyczące wydawania tymczasowych dowodów osobistych.

35 K. Czaplicki, op. cit., s. 83.

36 A. Dryszel, op. cit.

37 M. STAнL, Materialne prawo administracyjne: pojęcia, instytucje, zasady, Warszawa 2002, s. 96.

38 M. Wilczyńska, P. Wilczyński, Dowody osobiste, [w:] Prawo administracyjne materialne: pojęcia, instytucje zasady, red. M. STAHL, Warszawa 2013, s. 187.

39 Ibidem, s. 188. 
To właśnie ten akt prawny w art. 1 wprowadził obowiązek posiadania dowodu osobistego przez każdego obywatela polskiego od ukończenia 18. roku życia. Zgodnie z art. 5 ust. 1 tego dekretu dowody osobiste i tymczasowe zaświadczenia tożsamości ${ }^{40}$ były jedynymi dokumentami, stwierdzającymi tożsamość osób.

W latach 70. zdecydowano się na uregulowanie w jednej ustawie dwóch zagadnień, tj. prawa dowodów osobistych i ewidencji ludności. Zgodnie z ustawą z 10 kwietnia 1974 r. o ewidencji ludności i dowodach osobistych ${ }^{41}$ dowód osobisty stwierdzał tożsamość osoby i poświadczał obywatelstwo polskie. Zgodnie z art. 34 tej ustawy obowiązek posiadania dowodu osobistego dotyczył osoby będącej obywatelem polskim i zamieszkałej na terytorium Rzeczypospolitej Polskiej „od ukończenia 18. roku życia”, a także „od ukończenia 15. roku życia, jeżeli pozostaje w stosunku pracy lub nie zamieszkuje wspólnie z osobami, pod których władzą rodzicielską lub opieką się znajduje, albo nie pozostaje pod władzą rodzicielską lub opieką". Ustawa przyznawała także prawo do otrzymania dowodu osobistego osobie, która ukończyła lat 13. Dowód osobisty zawierał dwa rodzaje danych - dane pozwalające na stwierdzenie tożsamości osoby fizycznej oraz dane niezbędne przy dokonywaniu różnego rodzaju czynności faktycznych i prawnych ${ }^{42}$ lub określenia sytuacji prawnej posiadacza dokumentu ${ }^{43}$.

Zmiany ustrojowe po 1989 r. wpłynęły na system dowodów osobistych - między innymi dostosowano go do współczesnej nazwy Państwa i nowych symboli narodowych. 22 maja 1997 r. Sejm przyjął projekt zmian ustawy o ewidencji ludności i dowodach osobistych ${ }^{44}$. Ustawa przewidywała, że każdy obywatel Polski od ukończenia 18. roku życia

40 Zgodnie $\mathrm{z}$ art. 3 dekretu o dowodach osobistych był to dokument, wydawany osobie, której tożsamość lub obywatelstwo polskie nie zostały stwierdzone w sposób niewątpliwy.

41 Dz. U. z 1974 r. Nr 14, poz. 85.

42 Z. Ryвicki, S. PiĄTeK, Zarys prawa administracyjnego i nauki administracji, Warszawa 1984, s. 411.

43 Polskie prawo administracyjne, red. J. SŁużewski, J. LANG, M. WierzbowsKa, A. Wiktorowska, Warszawa 1995, s. 506.

44 Tekst jedn.: Dz. U. z 2016 r. poz. 722. 
bądź też od 15., jeżeli pozostawał w stosunku pracy lub nie pozostawał pod władzą rodzicielską lub opieką, lub też nie zamieszkiwał wspólnie z osobami, pod których opieką lub władzą rodzicielską się znajdował, miał obowiązek posiadać dowód osobisty. Obowiązek ten nie był tożsamy z posiadaniem go zawsze przy sobie. Jak wskazuje Marek Chmaj, w polskim prawie nie istnieje generalny i stały obowiązek noszenia dowodu osobistego ${ }^{45}$. Prawo (a nie obowiązek) do posiadania dowodu osobistego dotyczyło z kolei osób, które ukończyły 13. rok życia. Zarówno obowiązek, jak i prawo posiadania dowodu nie były uzależnione od posiadania przez daną osobę pełnej lub częściowej zdolności do czynności prawnych, w związku z czym dowód osobisty mógł być wydany osobie ubezwłasnowolnionej ${ }^{46}$. W 1997 r. zdecydowano także o zmianie wyglądu dowodu tożsamości - papierową książeczkę miała zastąpić karta z tworzywa sztucznego. Stare dokumenty miały obowiązywać do 31 grudnia 2005 r. Z uwagi na problemy, głównie techniczne i finansowe, termin wprowadzenia nowych dowodów osobistych przełożono ${ }^{47}$. Ostatecznie produkcja nowych dowodów osobistych rozpoczęła się 15 stycznia 2001 r., a stare dokumenty utraciły ważność 31 marca 2008 r. ${ }^{48}$

Dowody tożsamości wydawane po 15 stycznia 2001 r. zgodnie z $\$ 4$ rozporządzenia Rady Ministrów w sprawie wzoru dowodu osobistego oraz trybu postępowania w sprawach wydawania dowodów osobistych ${ }^{49}$ miały formę spersonalizowanej karty identyfikacyjnej o wymiarach $54 \mathrm{~mm} \times 85 \mathrm{~mm}$, wykonanej z tworzywa sztucznego, zawierającej dane osobowe, zdjęcie i podpis posiadacza, trzyliterową serię i sześciocyfrowy numer dowodu osobistego, nazwę organu wydającego dowód osobisty,

45 M. ChmaJ, Prawo administracyjne materialne, Warszawa 2008, s. 183.

46 Ibidem, s. 183.

47 K. Czaplicki, op. cit., s. 97.

48 P. JĘDRASIAK, Masz nowy dowód? 31 marca książeczkowe dowody traca ważność, http://www.wiadomosci24.pl/artykul/masz_nowy_dowod_31_marca_ksiazeczkowe_ dowody_traca_waznosc_62022.html (dostęp 30 października 2016 r.).

49 Rozporządzenie Rady Ministrów z 21 listopada 2000 r. w sprawie wzoru dowodu osobistego oraz trybu postępowania w sprawach wydawania dowodów osobistych, ich wymiany, zwrotu lub utraty (Dz. U. Nr 112, poz. 1182 ze zm.). 
datę wydania i termin ważności oraz elementy zabezpieczające dokument przed podrobieniem i fałszowaniem.

Nowego znaczenia obok potwierdzenia tożsamości i obywatelstwa nabrały dowody osobiste po wejściu polski do Unii Europejskiej, stając się dokumentem uprawniającym obywateli polskich do przekraczania granic państw członkowskich $U^{50}$. Jak zauważa Kamil Czaplicki, w chwili wejścia Polski do UE na terenie Polski obowiązywały dwa rodzaje dowodów osobistych. Pominięcie tego faktu w przepisach prawa oznaczało, że prawo przekraczania granicy z państwami członkowskimi przysługiwało zarówno posiadaczom nowych dokumentów, jak i posiadaczom starych książeczkowych dowodów osobistych ${ }^{51}$.

Kolejna ustawa, która wprowadziła wiele zmian do dowodu osobistego, weszła w życie 1 marca 2015 r. ${ }^{52}$ W odróżnieniu od wcześniejszego wzoru dowodu nowy dokument ma zmniejszony zakres danych widocznych w warstwie graficznej dokumentu ${ }^{53}$. Na dowodzie znajdują się dane dotyczące osoby (nazwisko, imię (imiona), nazwisko rodowe, imiona rodziców, data i miejsce urodzenia, płeć, wizerunek twarzy, numer PESEL, obywatelstwo) oraz dane dotyczące dowodu osobistego (seria i numer dowodu osobistego, data wydania i data ważności dokumentu, oznaczenie organu wydającego dokument). W przeciwieństwie do dokumentów wydawanych w poprzednich latach na dokumencie nie ma adresu zameldowania, podpisu posiadacza dokumentu, a także wzrostu i koloru oczu. Obecnie brak jest analizy wpływu usunięcia adresu na prawa i obowiązki obywateli. Można się jednak spodziewać, że utrudni to życie wielu obywatelom. Dane adresowe ułatwiają procedurę ustalenia tożsamości obywatela, ułatwiają określenie właściwości miejscowej urzędów czy też ustalenie lokalu wyborczego w wyborach powszechnych ${ }^{54}$.

50 M. ChMAJ, op. cit., s. 183.

51 K. Czaplicki, op. cit., s. 106.

52 Tekst jedn.: Dz. U. z 2016 r. poz. 391.

53 K. Czaplicki, op. cit., s. 126.

54 Ibidem, s. 127, [za:] E. Matyszewska, M. KryszkiewiCz, Ł. Kuligowski, Adres zameldowania zniknie z dowodu osobistego, «Gazeta Prawna» nr 75 z 16 kwietnia 2008 r. 
Porównując dowody osobiste z 1918 r., z 1974 r., z 2000 r. i te najnowsze z 2015 r., widać oczywisty wpływ technologiczny na ich wygląd. Zmiana podłoża z papierowego z płócienną okładką na wielopoziomowy poliwęglan grawerowany laserowo jest zmianą rewolucyjną, dzięki której dokumenty stały się nowoczesnym nośnikiem danych o obywatelach ${ }^{55}$. Niewątpliwie coraz trudniejsze staje się podrobienie dowodu osobistego, ponieważ zmianie uległy również zabezpieczenia dokumentów. Początkowo jedynym zabezpieczeniem były blankiet dokumentu, pieczęć i podpis wystawcy. Obecnie wśród katalogu zabezpieczeń jest blisko 15 technik umieszczonych na trzech poziomach odbioru: widocznym gołym okiem, widocznym przy użyciu specjalistycznych urządzeń oraz widocznym i znanym jedynie wydawcy dokumentu i służbom odpowiedzialnym za bezpieczeństwo państwa ${ }^{56}$.

\section{UstaWA O USEUGACH ZAUFANIA I IDENTYFIKACJI ELEKTRONICZNEJ}

Uchwalenie przez Sejm ustawy z 5 września 2016 r. o usługach zaufania i identyfikacji elektronicznej ${ }^{57}$ było następstwem wejścia w życie rozporządzenia Parlamentu Europejskiego i Rady (UE) nr 910/2014 w sprawie identyfikacji elektronicznej i usług zaufania publicznego w odniesieniu do transakcji elektronicznych na rynku wewnętrznym oraz uchylającego dyrektywę 1999/93/WE (eIDAS) ${ }^{58}$.

Rozporządzenie eIDAS implikuje nowy porządek prawny w obszarze usług zaufania, co zrodziło konieczność dostosowania prawa krajowego do nowych uwarunkowań ${ }^{59}$. Jak wskazano w uzasadnieniu do ustawy, w prawie polskim regulowana była dotychczas w sposób pełny jedynie instytucja podpisu elektronicznego (w tym zwłaszcza bezpiecznego pod-

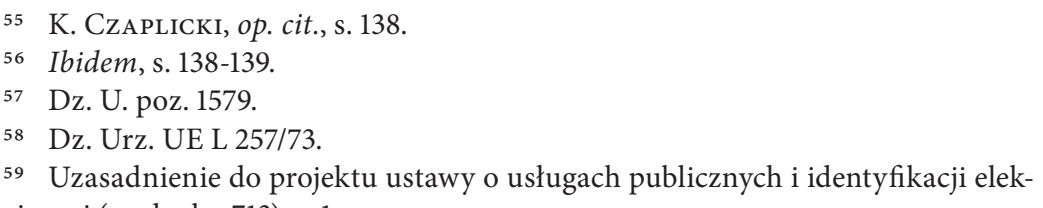
tronicznej (nr druku 713), s. 1. 
pisu elektronicznego) oraz znakowanie czasem. Rozporządzenie eIDAS poszerza gamę dostępnych usług oraz nakłada na państwa członkowskie obowiązek ustanowienia nadzoru. Kwestie dotyczące nadzoru usług zaufania oraz notyfikacji systemów elektronicznej identyfikacji stanowią najważniejszą treść nowej krajowej regulacji ${ }^{60}$. Ponadto rozporząadzenie wprowadziło nowy element, który nie zalicza się do usług zaufania identyfikację elektroniczną $\mathrm{w}$ celu realizacji usług online. Celem jest zapewnienie posiadaczowi środka identyfikacji elektronicznej wydanego w jednym kraju członkowskim możliwości skorzystania z publicznych usług online w innych krajach członkowskich ${ }^{61}$.

Art. 1 ustawy z 5 września 2016 r. o usługach zaufania i identyfikacji elektronicznej określa krajową infrastrukturę zaufania, działalność dostawców usług zaufania, w tym zawieszanie certyfikatów podpisów elektronicznych i pieczęci elektronicznych, tryb notyfikacji krajowego systemu identyfikacji elektronicznej, nadzór nad dostawcami usług zaufania.

Zadaniem uchwalonej ustawy było przede wszystkim wyeliminowanie pojęć i instytucji nieznanych w rozporządzeniu eIDAS i dostosowanie terminologii krajowych aktów prawnych do terminów występujących $\mathrm{w}$ tym rozporządzeniu ${ }^{62}$. Ponadto, regulowano te obszary, które niezbędne są do umożliwienia stosowania rozporządzenia eIDAS na gruncie prawa polskiego, tj. między innymi wyznaczono organ nadzoru ${ }^{63}$, a także uchylono ustawę z 18 września 2001 r. o podpisie elektronicznym (tekst jedn.: Dz. U. z 2013 r. poz. 262 ze zm.) oraz usunięto istniejące w krajowych przepisach odesłania do jej przepisów ${ }^{64}$.

W uzasadnieniu do projektu ustawy wskazano, że filarami dla realizacji kolejnych zmian będzie:

\footnotetext{
60 Ibidem, s. 1.

61 Ibidem, s. 5.

62 Komunikat ze strony Ministerstwa Cyfryzacji Prezydent podpisał ustawe o ustugach zaufania oraz identyfikacji elektronicznej, https://mc.gov.pl/aktualnosci/ prezydent-podpisal-ustawe-o-uslugach-zaufania-oraz-identyfikacji-elektronicznej (dostęp 12 października 2016 r.).

63 Ibidem.

64 Ibidem.
} 
- wykorzystanie istniejących już w Polsce różnych środków identyfikacji elektronicznej sprawdzonych w praktyce uwierzytelniania w usługach online świadczonych przez podmioty prywatne (np. banki);

- szerokie wykorzystanie nowych usług zaufania, takich jak: pieczęć elektroniczna, konserwacja elektroniczna i usługa rejestrowanego doręczania elektronicznego;

- usunięcie wielu barier formalnych, które wymuszają tworzenie dokumentów papierowych lub powodują, że posługiwanie się nimi jest nieraz wygodniejsze, bardziej bezpieczne, a nawet tańsze.

Wszystkie projektowane zmiany, jak zapowiedziała Minister Cyfryzacji Anna Streżyńska, mają w rezultacie doprowadzić do wprowadzenia mID (elektronicznych dowodów osobistych w smartfonie) w 2017 r. ${ }^{65}$

\section{Dotychczasowe dziąania Podejmowane W CELU WPROWADZENIA ELEKTRONICZNYCH DOWODÓW OSOBISTYCH}

Impulsem do rozpoczęcia prac nad elektronicznymi dowodami osobistymi było wprowadzenie paszportów biometrycznych ${ }^{66}$. Dnia 28 marca 2007 r. Rada Ministrów wydała rozporządzenie w sprawie Planu Informatyzacji Państwa na lata 2007-201067. Jak wskazano w uzasadnieniu do projektu ustawy o dowodach osobistych z 6 sierpnia 2010 r., nowy dowód osobisty miał spełniać wymogi określone rozporządzeniem z 28 marca 2007 r. Jednym z głównych elementów jest wdrożenie wielofunkcyjnego elektronicznego dokumentu tożsamości z uwierzytelnieniem, zgodnego z unijnymi koncepcjami narodowego dokumentu identyfikacyjnego (eID) w systemach IT jednostek sektora publicznego (administracja publiczna, pomoc społeczna, ochrona zdrowia itp.), który umożliwiać będzie potwierdzanie tożsa-

65 Wystąpienie Minister Cyfryzacji A. Streżyńskiej podczas Impact'16 16 czerwca 2016 r., https://www.youtube.com/watch?v=bImItn89CIg ( dostęp 13 listopada 2016 r.).

66 Por. K. Czaplicki, op. cit., s. 111.

67 Dz. U. z 2007 r. poz. 415. 
mości obywateli polskich ${ }^{68}$. Zgodnie z art. 11 projektu ustawy dowód miał posiadać warstwy graficzną oraz elektroniczną.

Dowód osobisty miał umożliwiać uwierzytelnienie go w systemach teleinformatycznych podmiotów publicznych, uwierzytelnienie jego posiadacza w systemach teleinformatycznych podmiotów publicznych oraz przy dostępie do rejestrów publicznych z użyciem systemów teleinformatycznych, jak również ograniczoną identyfikację posiadacza dowodu osobistego w systemach teleinformatycznych podmiotów publicznych.

Przepisy ustawy miały wejść w życie 1 lipca 2011 r. Kilka dni wcześniej, 9 czerwca 2011 r., Sejm przyjął ustawę o zmianie ustawy o dowodach osobistych i ustawy o ewidencji ludności ${ }^{69}$. Projekt ustawy wpłynął do Sejmu 19 maja 2011 r. i rozpatrywany był w trybie pilnym. Ustawa znowelizowała poprzednie przepisy i odroczyła wejście w życie ustawy z 6 sierpnia 2010 r. o dwa lata, czyli do 1 lipca 2013 r. W uzasadnieniu projektu ustawy z 9 czerwca 2011 r. jako powód nowelizacji w postaci zmiany terminu wejścia w życie ustawy o dowodach osobistych wskazano przesłanki natury funkcjonalnej, prawnej i technicznej, które wskazują na ryzyko niezakończenia przygotowań organizacyjnych i technicznych do wydawania dowodów osobistych nowego wzoru przed datą wejścia w życie nowych przepisów, tj. przed dniem 1 lipca $2011 \mathrm{r}^{70} \mathrm{~W}$ uzasadnieniu wskazano ponadto, że narzędziem zbliżonym funkcjonalnie do nowego dowodu tożsamości jest profil zaufany na platformie ePUAP, który w tej sytuacji może odegrać rolę skutecznego rozwiązania tymczasowego. Jak argumentowano, dzięki jego funkcjonowaniu możliwe będzie oferowanie usług elektronicznej administracji identycznych z tymi, które planowano budować na bazie dowodu osobistego ${ }^{71}$.

68 Uzasadnienie do projektu ustawy z 6 sierpnia 2010 r. (nr druku 2917).

69 Dz. U. z 2011 r. Nr 133, poz. 768.

70 Uzasadnienie do projektu ustawy o zmianie ustawy o dowodach osobistych i ustawy o ewidencji ludności (nr druku 4202).

71 Ibidem. 
Mimo wprowadzonych zmian i przeniesienia terminu wprowadzenia dokumentów ówczesne MSWiA nadal deklarowało pełną gotowość wprowadzenia elektronicznych dowodów tożsamości ${ }^{72}$.

W październiku 2012 r. pojawił się nowy rządowy projekt ustawy o zmianie ustawy o ewidencji ludności i dowodach osobistych oraz niektórych innych ustaw ${ }^{73}$, który ponownie przesunął wprowadzenie nowych dowodów osobistych, z jednoczesną rezygnacją z warstwy elektronicznej dowodu osobistego. Jako powód rezygnacji podano przeprowadzoną przez Komitet Rady Ministrów ds. Cyfryzacji analizę zasadności wdrożenia elektronicznego dowodu osobistego w Polsce, w której zarekomendowano przesunięcie terminu wdrożenia elektronicznych dowodów osobistych do czasu opracowania jednolitej polityki w zakresie uwierzytelniania obywateli w systemach teleinformatycznych administracji publicznej ${ }^{74}$. Ponadto zwrócono uwagę na toczące się w Komisji Europejskiej prace nad utworzeniem europejskiego rynku cyfrowego. Za celowe uznano przesunięcie w czasie wprowadzenia elektronicznych dowodów osobistych, aby rozwiązania, jakie zostaną zaproponowane $\mathrm{w}$ rozporządzeniu, nie były rozbieżne z przyjętymi w Polsce ${ }^{75}$. W uzasadnieniu do projektu w części „Ocena skutków regulacji” wskazano na wiele utraconych korzyści związanych z usunięciem warstwy elektronicznej w dowodzie osobistym zarówno po stronie administracji, jak i obywateli. Utracone korzyści dla administracji to brak jednolitego mechanizmu uwierzytelniania obywateli w organach administracji publicznej, oszczędności nakładów i czasu w związku z możliwością udostępnienia obywatelom drogą elektroniczną, dzięki wiarygodnemu mechanizmowi zdalnego uwierzytelnienia obywatela, usług publicznych, wymagających silnego uwierzytelnienia, na przykład złożenie

72 P. KoŁodziejczyк, Wystąpienie na 94. posiedzeniu Sejmu 7 czerwca 2011 r., sprawozdanie stenograficzne z 94. posiedzenia Sejmu Rzeczypospolitej Polskiej 7 czerwca 2011 r., s. 17-19, [za:] K. CzAPLICKI, op. cit., s. 122.

73 Rządowy projekt ustawy o zmianie ustawy o ewidencji ludności i dowodach osobistych oraz niektórych innych ustaw (nr druku 835).

74 Ibidem, s. 8.

75 Por. Uzasadnienie do rządowego projektu ustawy o zmianie ustawy o ewidencji ludności i dowodach osobistych oraz niektórych innych ustaw (nr druku 835), s. 8-9. 
wniosku o zmianę w księgach wieczystych, uzyskanie możliwości skorzystania z nośnika, jakim jest mikroprocesor w dowodzie osobistym, do umieszczenia w przyszłości dodatkowych danych bez konieczności budowy odrębnych systemów resortowych ${ }^{76}$. Za utracone korzyści dla obywateli uznano z kolei stworzenie możliwości szerokiego wykorzystywania w obrocie prawnym podpisu elektronicznego osadzonego w dowodzie osobistym, umożliwienie obywatelowi łatwiejszej kontroli nad jego danymi osobowymi zgromadzonymi w rejestrach państwowych, stworzenie obywatelowi możliwości potwierdzania jego prawa do ubezpieczenia zdrowotnego za pomocą osadzonej w dowodzie aplikacji eKUZ (elektroniczna karta ubezpieczenia zdrowotnego) ${ }^{77}$.

W dniu 23 lipca 2014 r. Parlament Europejski i Rada (UE) przyjęły rozporządzenie w sprawie identyfikacji elektronicznej i usług zaufania w odniesieniu do transakcji elektronicznych na rynku wewnętrznym oraz uchylające dyrektywę nr 1999/93/WE (eIDAS). Jak zauważa K. Czaplicki, projekt rozporządzenia przekazany został do Polski 8 czerwca 2012 r., czyli ponad pięć miesięcy przed debatą publiczną w Sejmie i pracami nad projektem ustawy znoszącym warstwę elektroniczną ${ }^{78}$. Ponadto poseł Wincenty Elsner podczas sejmowej dyskusji nad projektem ustawy przytaczał przepisy projektu rozporządzenia eIDAS, przekonując, że nie stoją one w sprzeczności z projektowaną ustawą ani na przeszkodzie wdrożeniu elektronicznych dowodów osobistych ${ }^{79}$.

\section{ObeCNiE PODEJMOWANE PRACE} NAD WPROWADZENIEM E-DOWODU

Implementacja dowodu z warstwą elektroniczną (e-Dowodu) była częścią projektu pl.ID, ale nie została ona zrealizowana w uzgodnionym z Komisją Europejską (KE) terminie. Dlatego projekt pl.ID otrzymał

76 Ibidem, s. 16.

77 Uzasadnienie do rządowego projektu ustawy o zmianie ustawy o ewidencji ludności i dowodach osobistych oraz niektórych innych ustaw (nr druku 835), s. 16.

78 K. CzAplicki, op. cit., s. 124.

79 Ibidem. 
status projektu niefunkcjonującego i aby uniknąć konieczności oddania 85\% już poniesionych kosztów kwalifikowanych (czyli 148 mln zł), musi dostarczyć rezultaty - czyli umożliwić rozpoczęcie wydawania e-Dowodów - do końca marca 2019 r.

Dnia 27 czerwca 2016 r. Ministerstwo Cyfryzacji, Ministerstwo Spraw Wewnętrznych i Administracji oraz Ministerstwo Zdrowia zawarły porozumienie w sprawie dalszych prac nad dowodem osobistym z warstwą elektroniczną.

Jak podkreślono w koncepcji „e-Dowód - kontynuacja projektu pl.ID i realizacja powiązanych projektów”, nowy elektroniczny dowód osobisty będzie w sposób jednoznaczny i niezaprzeczalny potwierdzał tożsamość obywatela, będzie też służył do uwierzytelnienia w e-usługach administracji publicznej oraz do podpisywania dokumentów w cyfrowym świecie. Oprócz tego będzie posiadał aplikację ICAO (dokument podróży z cechą biometryczną „zdjęcie twarzy”) i pozwalał potwierdzać obecność w placówkach służby zdrowia ${ }^{80}$.

Koncepcja zakłada, że nowe dowody będą wydawane od 2019 r. Obywatel będzie posiadał dokument tożsamości z warstwą elektroniczną, na której będą zapisane jego dane, a jednocześnie dzięki temu, że będą udostępniane wszystkim zainteresowanym podmiotom (publicznym i komercyjnym) darmowe narzędzia do wykorzystania identyfikacji i uwierzytelniania e-Dowodem w ich systemach informatycznych, stopniowo będzie rosła liczba miejsc, gdzie zamiast wypełniać papierowy wniosek będzie można po prostu przyłożyć e-Dowód do czytnika u danego świadczeniodawcy i podać PIN. W ten sposób skraca się czas obsługi klienta oraz zmniejszają się koszty jego obsługi (eliminacja papieru i pracochłonności), a także zwiększa bezpieczeństwo ${ }^{81}$.

Nowe elektroniczne dowody osobiste mają być wydawane po 1 stycznia 2019 r. Początkowo zakładano, że wszystkie dokumenty obecnie obowiązującego wzoru, wydane pełnoletnim obywatelom polskim, zostaną wymienione w okresie pięciu lat, tj. do 2023 r. ${ }^{82}$ Uznano jednak, że

${ }^{80}$ Koncepcja e-Dowód - kontynuacja projektu pl.ID i realizacja powiązanych projektów, s. 3.

81 Ibidem, s. 8.

82 Koncepcja wdrożenia dowodu osobistego z warstwą elektroniczną, s. 2-3. 
wymiana dowodów stanowi na tyle duże przedsięwzięcie organizacyjne, pociągające za sobą znaczące koszty ${ }^{83}$, i zdecydowano się na wariant naturalnej wymiany dowodów w okresie 10 lat $^{84}$. W nowym dowodzie mają znaleźć się dwa rodzaje danych - dane dotyczące osoby, tj. nazwisko, imię pierwsze, pozostałe imiona, nazwisko rodowe, imiona rodziców, datę i miejsce urodzenia, płeć, wizerunek twarzy, numer PESEL, obywatelstwo; oraz dane dotyczące dowodu osobistego, tj. serię i numer dowodu osobistego, datę wydania, datę ważności, oznaczenie organu wydającego dowód osobisty ${ }^{85}$. Zgodnie $\mathrm{z}$ zapowiedziami w warstwie elektronicznej dowodu osobistego nie będzie więcej danych niż w wersji graficznej. Należałoby się jednak zastanowić nad późniejszą możliwością rozszerzenia danych, które będą mogły znaleźć się w warstwie graficznej. Mogłoby to przybrać dwojaki charakter - z jednej strony, obywatel oprócz danych, które „obowiązkowo” miałyby się znaleźć w warstwie graficznej i elektronicznej, mógłby zdecydować, wybierając z katalogu danych fakultatywnych, czy a jeśli tak, to które z nich miałyby się dodatkowo znaleźć w wersji elektronicznej. Drugi wariant zakładałby, że zakres danych w wersji elektronicznej byłby niejako „obligatoryjnie” szerszy niż zakres danych umieszczonych w wersji graficznej.

Zdecydowano, że zamiast umieszczania w warstwie elektronicznej dokumentu dodatkowych danych, które podlegałyby późniejszej aktualizacji (ang. post-issuance), e-Dowód będzie wykorzystany jako klucz do usług udostępnianych przez systemy, w których gromadzone są dane (np. dla adresu zameldowania będzie to rejestr PESEL). Dzięki temu uzyskujemy gwarancję aktualności danych na e-Dowodzie względem Systemu Rejestrów Państwowych ${ }^{86}$. Obywatel po elektronicznym uwierzytelnieniu dowodem osobistym będzie miał możliwość wprowadzania/

83 Koncepcja e-Dowód - kontynuacja projektu pl.ID i realizacja powiązanych projektów, s. 4.

84 Ibidem.

85 Koncepcja: e-Dowód - kontynuacja projektu pl.ID i realizacja projektów powiązanych. Załącznik 2. Opis planowanej funkcjonalności i architektury IT oraz otoczenie prawno-organizacyjne, s. 5.

86 Ibidem, s. 6. 
zmiany danych osobowych w systemach e-administracji ${ }^{87}$. Dane zapisane w warstwie elektronicznej nie będą podlegały zmianie z wyjątkiem inicjalnie pustego kontenera dla użytku własnego obywatela ${ }^{88}$.

Warstwa elektroniczna ma na celu zabezpieczanie autentyczności dowodu osobistego. Podkreślono, że o ile elementy graficzne są podatne na modyfikacje (fałszerstwa), o tyle poprawnie zbudowana warstwa elektroniczna (dzięki zastosowanej kryptografii) uniemożliwia modyfikację chronionych informacji. Zastosowane rozwiązania techniczne mają uniemożliwić skopiowanie tej funkcjonalności, ponadto nie będzie możliwości nielegalnego wykorzystania poświadczenia przez osobę weryfikującą i poświadczania autentyczności tych danych wobec osób trzecich już bez udziału dowodu osobistego ${ }^{89}$.

Elektroniczny dowód osobisty pozwoli obywatelom na:

- identyfikację i uwierzytelnienie do systemów informatycznych online oraz bezpośrednio do systemu informatycznego administracji publicznej i komercyjnej poprzez interfejs z oprogramowaniem odpowiadającym za komunikację z e-Dowodem;

- elektroniczne podpisanie dokumentu przez obywatela w procesach online $\mathrm{z}$ administracją publiczną i służbą zdrowia;

- potwierdzenie obecności obywatela $\mathrm{w}$ procesach $\mathrm{z}$ administracją publiczną, służbą zdrowia i innych;

- możliwość odczytu danych zawartych w warstwie wizualnej $\mathrm{z}$ warstwy elektronicznej - w celu pobrania danych do procesu elektronicznego i w celu podwyższenia poziomu bezpieczeństwa dokumentu;

- możliwość przechowania dodatkowych danych do odczytu innych niż w warstwie wizualnej do indywidualnego wykorzystania przez obywatela;

- możliwość automatycznego przekraczania e-bramek kontroli granicznej na lotniskach UE (jako dokument podróży);

\footnotetext{
87 Ibidem.

88 Ibidem.

89 Ibidem, s. 13.
} 
- możliwość zainicjowania kwalifikowanego podpisu serwerowego od dowolnego dostawcy wybranego przez obywatela;

- możliwość użycia w przyszłości w urzędomatach (ZUS/US/nowe), czyli terminalach samoobsługowych do identyfikacji i uwierzytelnienia w usługach udostępnionych w terminalach ${ }^{90}$.

E-Dowód ma umożliwić złożenie podpisu elektronicznego zgodnego $z$ rozporządzeniem eIDAS dla zaawansowanego podpisu elektronicznego oraz umożliwić uwierzytelnienie na poziomie wysokim ${ }^{91}$.

$\mathrm{W}$ koncepcji wskazano na liczne korzyści wynikające $\mathrm{z}$ wprowadzenia elektronicznego dowodu osobistego; może na przykład służyć jako narzędzie kontroli dostępu w zakładach pracy i w innych instytucjach zamiast dotychczas stosowanych kart dostępu albo pozwolić na zdalną identyfikację w procesach, które do tej pory wymagały osobistego wstawiennictwa (np. rejestracja karty SIM, założenie rachunku bankowego; szczegółowe zastosowanie może wymagać zmiany przepisów szczegółowych) ${ }^{92}$. Skala, na jaką elektroniczny dowód osobisty będzie wykorzystywany, zależy jednak od tego, jak szybko systemy komercyjne zaakceptują autoryzację za pomocą e-Dowodu.

\section{CZY ELEKTRONICZNY DOWÓD OSOBISTY MOŻNA UZNAĆ ZA DOKUMENT URZĘDOWY?}

Jak wskazano wcześniej, dokumenty urzędowe charakteryzują następujące cechy:

a. są sporządzane przez organy państwowe;

b. organy te działają w ramach swej właściwości;

c. dokumenty te mają formę wyznaczoną przez prawo.

Rozważając, czy można będzie klasyfikować elektroniczne dowody osobiste jako dokumenty urzędowe, należy ocenić, czy spełniają one powyższe przesłanki.

90 Ibidem, s. 1-2.

91 Ibidem, s. 3.

92 Koncepcja e-Dowód - kontynuacja projektu pl.ID i realizacja powiązanych projektów, s. 8. 
Zgodnie z projektem ustawy z 24 kwietnia 2018 r. o zmianie ustawy o dowodach osobistych oraz niektórych innych ustaw nowe elektroniczne dowody osobiste mają być wydawane przez organ gminy. Zadania wskazane w ustawie, nałożone na te organy, są zadaniami zleconymi z zakresu administracji rządowej.

Nowe dowody elektroniczne będą miały taką samą postać jak dotychczas, choć zostanie ona wzbogacona o warstwę elektroniczną, pozwalającą na elektroniczną identyfikację i uwierzytelnianie posiadacza dowodu. Projektowana nowelizacja przepisów nie przewiduje więc takich zmian, które mogłyby mieć wpływ na pozbawienie elektronicznego dowodu osobistego cechy dokumentu urzędowego.

\section{Podsumowanie}

Elektroniczne dowody tożsamości są ideą, która już niebawem ma stać się faktem. Warstwa elektroniczna dowodu osobistego jest już europejskim standardem. Na kontynencie europejskim dowody elektroniczne ma już 26 państw. Zakres danych, które mają się znaleźć w nowym elektronicznym dowodzie osobistym, jest tożsamy z zakresem danych znajdujących się w obecnych dowodach. Takie same dane będą widniały $\mathrm{w}$ warstwie graficznej i elektronicznej i w tym zakresie należałoby rozważyć, czy to nie ograniczy jego funkcjonalności. Ciekawym rozwiązaniem wydaje się z kolei połączenie dowodu osobistego $\mathrm{z}$ kartą ubezpieczenia zdrowotnego. Dowód osobisty ma służyć jako klucz usług udostępnianych przez systemy, w których gromadzone są dane ${ }^{93}$. Niewątpliwie najistotniejszą sprawą jest zapewnienie bezpieczeństwa danych i wdrożenie rozwiązań opierających się na zasadach privacy by design i privacy by default. Pierwsze z nich (privacy by design) zakłada włączenie ochrony prywatności w samo tworzenie projektu, w działanie jego składników oraz w zarządzanie technologiami informacyjnymi i systemami przez

93 Ibidem, s. 6. 
cały cykl życia informacji94. Z kolei privacy by default to uwzględnienie jak najdalej posuniętych zabezpieczeń prywatności w ustawieniach domyślnych (początkowych) takiego systemu ${ }^{95}$. Umieszczanie w jednym miejscu tylu istotnych danych o obywatelu niesie za sobą ryzyko padnięcia ofiarą kradzieży tożsamości. Jak podkreśla Arkadiusz Lach, może to być szczególnie groźne dla pokrzywdzonego zwłaszcza w przypadku danych niezmiennych (np. data i miejsce urodzenia) czy też trudnych do zmiany (np. nazwisko). Stąd też skutki kradzieży tożsamości pokrzywdzony może odczuwać jeszcze wiele lat po nieautoryzowanym wykorzystaniu jego danych ${ }^{96}$.

Problemem nie wydaje się jednakże kwestia osób, które nie korzystają na co dzień z urządzeń mobilnych, ponieważ nadal będą mogły posługiwać się plastikowym dowodem osobistym. Jak podkreśla Karol Manys, tradycyjne dokumenty pozostaną. Każdy będzie miał jednak wybór, czy chce je nosić ze sobą w wypchanym portfelu, czy mieć w wygodnej formie na smartfonie ${ }^{97}$.

Obywatelom pozostaje oczekiwać na to zapowiadane rozwiązanie, które usprawni, ułatwi i skróci czas załatwiania spraw urzędowych. Jak pokazuje doświadczenie innych krajów europejskich, na przykład Estonii, gdzie mobilne dowody tożsamości istnieją od 2007 r., takie rozwiązanie sprawdza się w praktyce, a jego popularność wynika z łatwości użytkowania ${ }^{98}$.

Polska jak najszybciej powinna wdrożyć dowody osobiste z warstwą elektroniczną nie tylko z uwagi na termin wyznaczony przez Komisję, lecz także aby nie pozostawać w tyle za technologicznie rozwijającą się

94 W.R. Wiew Iórowski, Privacy by Design jako paradygmat ochrony prywatności, [w:] Internet. Prawno-informatyczne problemy sieci, portali i e-usług, red. G. SzPor, Warszawa 2012, s. 14.

95 Ibidem, s. 17.

96 A. LACH, op. cit., s. 30.

97 P. OsıŃski, Już w 2017 r. dowód osobisty będzie... aplikacją na smartfon!, http:// superbiz.se.pl/nowoczesne-technologie/juz-w-2017-r-dowod-osobisty-bedzie-aplikacja-na-smartfon_852788.html ( dostęp 2 stycznia 2017 r.).

98 K. PopєAwski, W Estonii już 100000 osób korzysta z mobilnych dowodów, http:// przegladbaltycki.pl/3071,estonii-juz-100-000-osob-korzysta-mobilnych-dowodow.html (dostęp 2 stycznia 2017 r.). 
Europą. Dotychczasowe doświadczenia związane z bankowością internetową pokazują natomiast, że można zaprojektować rozwiązanie tak, aby było nie tylko łatwe w użyciu, ale przede wszystkim bezpieczne.

\section{ELEKTRONICZNE DOWODY OSOBISTE}

\section{Streszczenie}

Elektroniczne dowody osobiste są wprowadzone w większości europejskich krajów. Polska planuje wprowadzić e-Dowód w pierwszym kwartale 2019 r. Prace nad elektronicznym dowodem osobistym trwają już ponad 10 lat, a pierwszym impulsem do ich rozpoczęcia stało się wprowadzenie paszportów biometrycznych. Nowy dowód ma posiadać warstwy graficzną i elektroniczną - zakres danych w obu warstwach będzie tożsamy. W koncepcji „e-Dowód - kontynuacja projektu pl.ID i realizacja powiązanych projektów" wskazano, że nie przewiduje się rozszerzenia zakresu danych $\mathrm{w}$ dowodzie elektronicznym w stosunku do danych znajdujących się w obecnych dowodach osobistych. Artykuł przedstawia najważniejsze pojęcia związane z dowodami osobistymi, proces ich wdrażania w Polsce oraz analizuje obecne prace podejmowane nad wprowadzeniem e-Dowodu w Polsce.

\section{Electronic ID CARDS}

\section{Summary}

Most European countries have brought in electronic ID cards. Poland is planning to introduce them in the first quarter of 2019. Work on the electronic identity card has been going on for over 10 years and the first impulse for starting the project was the introduction of biometric passports. The new Polish ID card will have a graphic and electronic layer and the range of data in both layers will be identical. The Polish electronic ID card, which is the continuation of the pl.ID project and the implementation of related projects, does not envisage more data in relation to the data on the current identity cards. This article presents 
the chief concepts relating to identity cards, their implementation in Poland, and it examines the work currently being done to introduce electronic ID cards in Poland.

Słowa kluczowe: dokument; elektroniczne dowody osobiste; rozporządzenie eIDAS; tożsamość.

Keywords: document; electronic ID cards; the eIDAS Regulation; identity.

\section{Literatura}

BŁAchuт J., Dokument jako przedmiot ochrony prawnokarnej, Warszawa 2011.

Czaplicki K., Dokumenty tożsamości. Jawność i bezpieczeństwo, Warszawa 2016.

Demendecki T., Komentarz aktualizowany do art. 244 Kodeksu postępowania cywilnego, [w:] Kodeks postępowania cywilnego. Komentarz aktualizowany, I:, Art. 1-729, red. A. JA KuBECKI, Warszawa 2018, s. 438-462.

Doroszewski W., Słownik języka polskiego, IX, Warszawa 1967.

DuBIsz S., Uniwersalny słownik języka polskiego PWN, t. A-J, Warszawa 2006.

Dunaj B., Popularny słownik języka polskiego, Warszawa 2001.

JaśKowska M., Wróbel A., Komentarz bieżacy do ustawy $z$ dnia 14 czerwca 1960 r. - Kodeks postępowania administracyjnego, Warszawa 2016.

Knoppex K., Dokument w procesie cywilnym, Poznań 1993.

Kuligowski Ł., Kryszkiewicz M., Matyszewska E., Adres zameldowania zniknie z dowodu osobistego, "Gazeta Prawna» nr 75 z 16 kwietnia 2008 r.

LACH A., Karnoprawna reakcja na zjawisko kradzieży tożsamości, Warszawa 2015.

Lang J., SŁużewski J., Wierzbowska M., Wiktorowska A., Polskie prawo administracyjne, Warszawa 1995.

Marshall G., Słownik socjologii i nauk społecznych, Warszawa 2004.

Mordini E., Biometria i biopolityka, «Człowiek i Dokumenty» 8/2008, s. 19-24.

Ochendowski E., Postępowanie administracyjne ogólne, egzekucyjne i sądowoadministracyjne. Wybór orzecznictwa, Toruń 2010.

Osıński P., Już w 2017 r. dowód osobisty będzie... aplikacją na smartfon!, http:// superbiz.se.pl/nowoczesne-technologie/juz-w-2017-r-dowod-osobisty-bedzie-aplikacja-na-smartfon_852788.html. 
PopŁAWski K., W Estonii już 100000 osób korzysta z mobilnych dowodów, http:// przegladbaltycki.pl/3071,estonii-juz-100-000-osob-korzysta-mobilnych-dowodow.html.

Przy bysz P.M., Kodeks postępowania administracyjnego. Komentarz aktualizowany, Warszawa 2018, «Lex» nr 10688.

WiewióRowski W.R., Privacy by Design jako paradygmat ochrony prywatności, [w:] Internet. Prawno-informatyczne problemy sieci, portali i e-ustug, red. G. SzPoR, Warszawa 2012, s. 13-29.

Wојsчк K., Dokument jaki jest każdy widzi... a jaki będzie?, «Człowiek i Dokumenty» 15/2009, s. 8-14. 